\title{
LA EDUCACIÓN EN LOS MEDIOS Y LA ACTIVIDAD CIUDADANA
}

\author{
MEDIA EDUCATION \\ AND ACTIVE CITIZENSHIP ${ }^{1}$
}

Concepción Naval

Elena Arbués

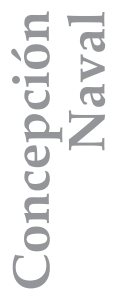

Catedrática. Decana de la Facultad de Educación y Psicología (Universidad de Navarra). Visiting Fellow and Oliver Smithies Lecturer, en Balliol College, University of Oxford, y Visiting Faculty en Teachers College, Columbia University (2012-13). En 2010 inició, y desde entonces dirige, el proyecto «Parlamento cívico» financiado por el Parlamento Foral de Navarra; y desde 1997, el Grupo de investigación consolidado: «Educación, ciudadanía y carácter» (GIECC). Investigadora principal del proyecto: «Researching and promoting character education in Latin American secondary schools (2016-18)», financiado por la World Templeton Charity Foundation.

Correo electrónico: [cnaval@unav.es].

Profesora Contratada Doctora (Universidad de Navarra). Dirige el Máster Universitario en Profesorado (Universidad de Navarra). Ha realizado una estancia de investigación post-doctoral en Balliol College, Holywell Manor, University of Oxford. Su investigación se centra en la educación cívica, el fomento de la participación social y la enseñanza de las ciencias. Miembro del Grupo de Investigación «Educación, ciudadanía y carácter» (GIECC) de la Universidad de Navarra.

Correo electrónico: [earbues@unav.es].

1 This work has been carried out within the framework of Parlamento Cívico Project, funded by the Foral Parliament of Navarra (2010-2016), during a period of research carried out by the authors at the University of Oxford. 


\title{
RESUMEN
}

En la sociedad de la información y de la comunicación, la educación mediática es esencial. Parte del debate que la comunidad educativa mantiene sobre este tema se enmarca en torno a dos cuestiones: ¿por qué educar para el uso de las tecnologías de la información y de la comunicación?; ¿cómo y quién se encarga de este cometido? (Potter, 2010). En este trabajo, trataremos de profundizar en ellas, centrándonos en las políticas educativas adoptadas en diversos países europeos y en las recomendaciones de algunos organismos internacionales (Informe del Parlamento Europeo 2008/2129 (INI). Nuestro interés es contribuir, en alguna medida, a lograr una pedagogía mediática adecuada que favorezca el fomento de la competencia social y cívica y, en última instancia, los conocimientos y las habilidades de participación que conforman el saber ciudadano.

Palabras clave: alfabetización mediática, competencia mediática y digital, competencia social y cívica, ciudadanía digital, saber ciudadano.

\begin{abstract}
Media education has become a necessity in the world of information and communication. Part of this debate that is being considered by the teaching community focuses on two main issues: Why should we educate on the use of information and communication technologies? How should this be done and by whom? (Potter, 2010). In this paper, we will study these issues in-depth, whilst focusing on various European educational policies in addition to recommendations made by several international organizations (European Parliament Report 2008/2129 (INI). Our aim is to contribute to this debate, as far as possible, with an appropriate media pedagogy plan that promotes social and civic competencies, which will ultimately lead to acquiring the knowledge and skills needed for good citizenship.
\end{abstract}

Key words: media literacy education, media and digital competence, social and civic competence, digital citizenship, citizen knowledge. 


\section{INTRODUCTION}

The information and communication society where we live is characterized by the chance it gives us to access, store and transmit information, to create awareness and to continue life-long learning (Sancho, 2001). From the perspective of education, this fact demands consideration and emphasis of certain aspects, thus offering appropriate media education working towards active and participative citizenship. It is clear that this area is important in family and media area; nevertheless, our framework is formal education.

Our objective is to reflect on the potential of proper use of technological media to transmit citizen knowledge. That is, to promote the knowledge and skills needed for citizen participation which are the foundations of social and civic competences.

There is an open debate among the teaching community in this field on why education is needed on ICT use, and, in particular, how this task should be carried out and by whom (Campuzano, 1992; Morán, 1996; Sancho, 2001; Potter, 2010). This work will try to address these two questions, focusing on the reasoning behind some relevant points.

Tackling the first question, «Why should we educate on using information and communication technologies?», we cannot ignore the fact that we live in a world where ICT has an enormous influence on how we organize our lives, how we behave, our daily habits and, in general, how we see and understand the world (Pavón, 2005). The expression «digital life» is becoming more and more common. ICT can be found in an increasing variety of areas such as work, leisure, entertainment, information, participation, learning, social relations, means of communication, etc. Thus citizens must learn these new languages and how to discern and critically assess the vast amount of information on offer.

On this issue, media literacy has an important role to play in terms of circulating scientific knowledge in the media (Rosenbaum et al. 2008), in a society where diverse social groups with different cultural traits coexist. However, in relation to technology, it seems that they all share habits and tools. Technical culture might be said to be part of the culture of any given group (Pavón, 2005), and so technological media should provide a means to improve communication between cultural 
groups and social participation. This, in our opinion, is an important point that must be emphasized when answering the question on why the new technologies should be taught; this will be covered in the final point.

Although media and digital education is actually happening albeit with some difficulty, the truth is that, at present, it is a priority for both educational systems and major international organizations. As stated by Kubey (2003), «a worldwide movement in media literacy education has been growing for roughly twenty-five years now and has been marked by a number of recent developments» (352). Undoubtedly national education systems in Europe reflect this reality and endeavour to offer appropriate media education for their citizens.

To a great extent, the teachers of these subjects share curricula, research and strategies, and media competence is an objective in education found in more and more countries (Martens, 2010); however, the concept of media literacy is still controversial and divisive (Potter, 2010). Competence-based curricula refer to this part of education as media and audiovisual competence, but many terms have been used over the last few decades.

According to literature reviews by Bawden (2008) and Gallado (2013), the term used in the 80s was Computer Literacy, referring to a level of experience and familiarity with computers and computer applications (Hawkins and Paris, 1997).

The 90s popularised the term Information Literacy, rooted in the academic disciplines of Library and Information Science. Bundy (2004) defines information literacy as a set of skills allowing individuals to recognize when the information is necessary and to be capable of finding, evaluating and using it effectively.

The term Digital Literacy was introduced by Gilster (1997), who defines it as the ability to understand and use information in multiple formats from a wide range of sources when it is presented via computers. This term means more than the mere capacity to use software or work a digital gadget; it represents an individual's ability to perform tasks efficiently in a digital area. 
In 2007, the European Council and Parliament set up the frame of reference on key skills for lifelong learning. These skills include Digital Competence, which is defined as «the confident and critical use of Information Society Technology for work, leisure and communication» (EU Commission, 2007, 7). It indicates that necessary skills include using computers to retrieve, assess and store information; using the data in a critical and systematic way; using tools to produce, present and understand complex information; using technology to support critical thinking, creativity and innovation. This competence demands a critical and reflexive attitude. It is also revolves around participating in communities and networks with cultural, social or professional aims.

Yet another term related to Digital Competence, although used more broadly, is Media Literacy. For Pérez-Tornero and Martínez (2011), both concepts express the importance of acquiring new competences and skills in the field of ICT and the media. Media Literacy fits into the wider framework of cultural transformation where electronic and digital media converge.

Media Education is the term recommended recently by the EU Parliament to refer to media literacy. In 2008, the European Parliament stated the need for media education to be part of all curricula, at every level of primary and secondary education, introducing a subject called Media Education in schools (European Parliament Report 2008/2129 (INI). It remains to be seen whether this recommendation will be observed, but it is quite clear that there has been a consensus for decades that the main arena for digital literacy should be formal education (Gutiérrez \& Tyner, 2012) and there are good reasons for including it curricular content (Campuzano, 1992; Masterman, 1993; Ferrer \& Alcantud, 1995; De Pablos, 1996; Mena et al., 1996; García-Valcarcel, 2003; Fuentes, 2007). Now we will look at how it has been introduced in some European countries ${ }^{2}$.

2 Cfr. Naval y Arbués (2013). «Training in media and audiovisual competence». $7^{\text {th }}$ Annual Conference Democratic Citizenship and Human Rights Education. Birbeck, University of London and Institute of Education (28 June 2013). 


\section{MEDIA EDUCATION IN THE UK EDUCATION SYSTEM}

A wide variety of initiatives have been run in different countries in the $20^{\text {th }}$ century to tackle this urgent task, always within the framework of promoting active citizenship.

If we very briefly consider what happens in countries like Germany, France and Spain, we find that they coincide to a certain extent on some aspects, such as (Gómez Vaquero and García, 2002; Federici, Mamberto and Orlandini, 2003; Bevort, 2007; Gabelas, 2007; Rivoltella, 2007; Tulodziecki and Padeborn, 2007):

1) Media education began with the arrival of modern mass communication media.

2) Subsequently, ITC teaching became cross-curricular or through programmes focusing mainly on technical or procedural aspects.

3) At present, competence-based curricula include aspects relating to learning media competency.

4) In this area, gaps are still found in initial and on-going teacher training ${ }^{3}$.

The UK has forged a tradition in this field. The Government has provided noteworthy support and impetus since the 1930s and the role of British educational radio and television has been outstanding since 1924 (García Jimenez, 1982), although it was not until 1959 that it became a permanent and regular service. It would appear that the UK is unique in its administration and educational policy as it gives independence both to local school managers and educational organizations, and to the open system. He also emphasises the BBC's interest in education and how well it is received by teaching professionals due, on the one hand, to a lasting tradition in audiovisual pedagogy, and,

3 For further information on this issue in other countries, Martens (2010) may be consulted. This paper deals with the situation in multiple countries such as the USA, Australia, Canada, Malta, Slovenia, Singapore, China, India and Vietnam. 
on the other, to the $\mathrm{BBC}^{\prime}$ 's own education policy, which gives priority to the teaching staff's proficiency.

One possible explanation for this course of events in the UK lies in the work developed by British governments since 1933, when the British Film Institute (BFI) was founded as a cultural organization with a broad educational role ${ }^{4}$. The BFI has played an outstanding role in audiovisual education. Even back in the 70s, its policy helped to develop film studies in higher education as a degree course subject, and as a possible exam subject for 16-year-old students in secondary education. This policy confirmed the academic status of film studies and created posts for teachers in these subjects; it was also included in education budgets. Later, in the 80s, the BFI Department of Education played an important role in developing media education in schools by publishing textbooks and teaching material, and giving courses and conferences to support teachers who were interested in audiovisual education (Bazalgette, 1996).

This support and impetus given by the government and civil society since the 1930's has, in our opinion, contributed to creating the aforementioned network of organizations, which support and encourage schools giving media education. In the $90 \mathrm{~s}, 72 \%$ of secondary school pupils studied the media, cinema and television. Most of these courses require students to carry out practical work where they develop technical and creative skills through creating a media product. In addition, official examinations give a certain amount of prestige to this area of education (Hart and Hicks, 2002; Bazalgette, 2007a). It is not mere chance that the UK set up a task force made up of the Film Council, British Film Institute, BBC and Channel 4, fostering the idea of drawing up a media literacy charter in the United Kingdom, aiming to provide a unified definition of media literacy (Bazalgette, 2007b). They were eventually joined by other organizations which gave relevance to the Charter at a European level. It was released in 2006 under the title The European Charter for Media Literacy 5 .

4 Cf. http:/ / industry.bfi.org.uk/ (accessed $13^{\text {th }}$ June 2013).

5 The Charter exists to support establishing media literacy across Europe. By signing the Charter, individuals and associations commit to developing it. Cf.

http:/ / www.euromedialiteracy.eu/ charter.php?id=6 (accessed 13th June 2013). 
It seems that the institutional support offered to teachers has been a key issue giving great impetus to media education in the UK. We find it interesting to refer to the results of one of the most recent studies run by the Department for Education (DfE) in January 2012. ${ }^{6}$ The secondary schools chosen for this study stood out for their good praxis in the use of technology and improvements to teaching and learning. The results show:

- The teachers were prepared to incorporate technology into their teaching and into curriculum planning.

- The schools' commitment to sharing good practices.

- There is a constant effort to integrate technological progress, prioritised by educational criteria.

- The schools have successfully used educational platforms which extend education beyond the classroom and the school timetable, increasing parental participation and maximizing collaboration with other centres.

- The schools invest in technical assistance which guarantees the quality and reliability of the equipment.

Although the study does not mention specific pedagogical practices, these results suggest the need to focus research work on the keys to effective education. We shall now look at some contributions along this line.

\section{PEDAGOGICAL PERSPECTIVE}

Some international institutions and organizations such as UNESCO, the UN, the European Parliament and the Council of Europe have

6 Department for Education (2012). Using technology to improve teaching and learning in secondary schools. In: http://www.education.gov.uk/schools/ teachingandlearning/curriculum/ a00201823/ digital-technology-in-schools (Accessed 27th June 2013). 
promoted media education by establishing lines for work and pedagogical intervention as a global necessity in present-day society and as a strategy to develop populations (Aguaded, 2009; European Commission, 2009; García-Ruiz and Renés, 2013).

In its report on communication media literacy in a digital world (2008/2129 (INI), the European Parliament addresses the issue of media literacy in schools, and requests that media literacy be added as a ninth key competence in the European reference framework for lifelong learning (in accordance with EU Parliament Recommendation 2006/962/CE and the Council Recommendation, of 18 December 2006). It also suggests incorporating obligatory media pedagogy modules for teachers at all school levels to make the training intensive. It urges the competent national authorities to publish measures for using audiovisual media in teaching and problems regarding media education to all teaching staff in all subjects and in all types of school. We might also mention the EU Parliament recommendation that media education should be taught as a subject.

As curricula inclusion is clear, the following step is to clarify its curricular elements, that is, develop media pedagogy, as the EU Parliament itself calls it, which will decide on the concepts, procedures and attitudes that will shape the curriculum for this subject.

We now need to step back and consider some of the recommendations made by UNESCO over the last few years related to citizenship. This organization takes media and computer literacy as a discipline in an attempt to give people basic knowledge of the role of communication media and information devices in democratic societies. It includes a range of essential skills and knowledge for people in the $21^{\text {st }}$ century including the chance to take part in the media system, develop critical attitudes and gain lifelong knowledge to help develop society and become active citizens (Wilson et al., 2011). Thus media literacy is made up of certain types of knowledge and competences.

With reference to knowledge types, UNESCO (2011) proposes the elements within media and information literacy, and differentiates between them. On the one hand, it deals with information literacy, refering to the importance of access to information plus evaluation 
and ethical use of this information. This includes the following points: defining and articulating information needs, finding and assessing information, organizing it, and using ICT knowledge to process information. On the other hand, it addresses the issue of media literacy, which is the skill to understand media functions, appraise how these functions are performed and an opportunity for self-expression. Media literacy also implies understanding the role and functions of the media in democratic societies, comprehension of conditions where the media can fulfil its roles, critical evaluation of media content taking into account its functions, commitment to the media for self-expression and democratic participation, and, finally, revision of skills needed to produce content.

In an earlier document, the result of an expert group meeting held in Paris (UNESCO, 2008), media and information literacy were defined as critical thinking for «receiving and producing mass communication media. This implies knowledge of personal and social values, responsibilities relating to the ethical use of information, as well as participation in cultural dialogue and the maintenance of autonomy in a context where influences eroding that autonomy may be particularly subtle. Media and information literacy may be summed up as being centred on five core competencies, referred to as the "5Cs": Comprehension, Critical thinking, Creativity, Cross-cultural awareness and Citizenship» (UNESCO, 2008, 6).

It is our belief that these skills (5Cs), together with the aforementioned knowledge, should form the bases for student learning. Regarding the concept of media citizenship, we believe it is necessary for the task of fostering participative and communication skills for critical, profoundly democratic citizens, who will be properly prepared to enjoy this knowledge society (Gonzálvez, 2012; Hoskins et al., 2015). We shall now consider the opinions of some outstanding authors on the subject.

\section{MEDIA COMPETENCE AND CITIZENSHIP}

If we analyse the mediatory role played by media literacy, we find that, apart from its intrinsic value, it can also have positive effects or 
minimize negative aspects in several applied areas, such as active citizenship, public health or aesthetic education (cf. Martens, 2010, 6-8). These effects are varied: individual and social; cognitive, affective, attitudinal, psychological and behavioural.

Nowadays, it is common to find authors who believe that media education is vital for everyone, in a society where the mass media is a fundamental social institution (Guo-Ming, 2007, 91), and that they can play an important role in developing critical thinking. Livingstone $(2004,11)$ states «not only as selective, receptive, and accepting but also as participating, critical; in short, not merely as consumers but also as citizens». And Kubey (2003) follows the same line of thinking when he says that the mass media are «the precise means by which citizens receive nearly all of their information about political processes and elections. One can scarcely even think today about civics, elections, government, the constitution, or the Bill of Rights without also thinking about the media through which we learn of one issue, conflict, or campaign after another» (70).

Therefore, we might say that media education is an education for participation. It teaches citizens to participate by fostering a critical sense in the current media-saturated society (Buckingham, 2007; Thoman and Jolls, 2004).

Indeed, there are many authors who state that learning how media communication programmes are made is an excellent way of demystifying the media and gaining awareness of their working and influence (Martens, 2010, 6-7). As Higgins points out, «These production and interpretation skills would not only allow persons to become more discriminating viewers, but allow them also to actively speak out in the media - contributing to the so called electronic marketplace of ideas» (Higgins 1999, 625).

Livingstone $(2004,8)$ also comments: «in key respects, content creation is easier than ever. [...] Many [pupils] are already content producers, developing complex literacy skills through the use of e-mail, chat, and games. The social consequences of these activities - participation, social capital, civic culture - serve to network (or exclude) today's younger generations. At present, cementing content creation within 
media literacy programs requires further research to establish the relation between reception and production in the new media environment, together with further clarification of the benefits to learning cultural expression, and civic participation».

More specifically, Martens (2010, 7) mentions a considerable number of authors who have studied how media education can reduce the effects of race, class or gender stereotypes, which mass media texts often include.

On the matter of racial prejudice Ramasubramanian and Oliver (2007) affirm «when media consumers become more conscious of the role of media in actively shaping social reality, they will be less likely to be influenced by the biased, one-dimensional portrayals of racial groups in the media» (Ramasubramanian 2007, 252).

And again Vargas and DePyssler $(1998,407)$ correctly point out how «media misrepresentations of immigrants, and particularly Mexicans, play a significant role in shaping public attitudes and opinion. [...] This influence calls for a commensurate educational response, one that alerts students to the power of the media, enables them to apply critical skills when examining media texts, and helps them problematize their media experiences».

Finally, Reichert et al. (2007) demonstrate the efficacy of media education in the context of the objectification of the image of women in advertising. And Steinke et al. (2007), among others, when considering this aspect of education, point out that learning to "critically evaluate media content and that this critical evaluation can change the ways in which the content is processed and internalized» (42).

Thus, we believe that education on media competence and social and civic competence share common aspects, and so all efforts to encourage media literacy among young people will affect and improve their civic training and vice versa. This implies that, by working on specific aspects of media literacy in the classroom, we can insist on certain points that favour students' civic participation as an example; and that when developing social and civic competences in the school area we must not ignore the use of the media and exercising citizenship 
in the digital area. Among these common aspects we may consider the following:

- freedom of expression and information in a democratic society;

- the media as public services;

- pluralism in the media;

- the importance of the media for the cultural expression of society;

- intercultural dialogue;

- social participation through the media;

- the communication media and globalization.

\section{YOUNG PEOPLE AND MEDIA PARTICIPATION}

Young people have their citizenship experiences in digital spaces, among others (Sloam, 2014). The Ofcom report (2012) indicates that young people are prolific users of social media, where they claim to have a huge number of friends: 8 to 11-year-olds have an average of 92 friends, and 12 to 15 -year-olds have 286. This is an important point to be taken into account as, in this context, they present and share their biographies, feelings and experiences, construct their identities and learn behavioural norms (Buckingham \& Martínez-Rodríguez, 2013).

During the academic year 2011-2012 at the University of Navarra we carried out a field study on a sample of 1,250 students in an attempt to assess the civic commitment index among the students ${ }^{7}$. We believe that the citizen participation level is at the core of civic learning and

7 A detailed description of the work carried out and the methodology used can be found in: Reparaz, C., Arbués, E., Naval, C. y Ugarte, C. (2015). El índice cívico de los universitarios: sus conocimientos, actitudes y habilidades de participación social. Revista española de pedagogía, 260, 23-51. 
that participation is promoted by civic commitment. In order to participate, university students need to have a certain amount of civic knowledge which will allow them to form standards for action, and develop the attitudes and skills that will truly permit them to participate and collaborate in society.

To carry out this study, we prepared an assessment tool which allowed us to obtain information on three aspects. The tool consists of a knowledge test on civic education, a scale of civic commitment attitudes and a questionnaire on participation and civic commitment skills. At this point we merely wish to emphasise some results concerning the students' media participation.

The Questionnaire on participation and civic commitment skills focuses on both intellectual and social skills. As intellectual participation and civic commitment skills we have considered the following:

- problem-solving;

- reflection and critical thinking;

- analysis and synthesis;

- decision-making;

- learning to learn.

And also, among the social participation and civic commitment skills we have considered:

- cooperation;

- oral, written and active listening communication skills;

- teamwork;

- negotiation skills and the capacity to defend one's own opinion;

- respect for the opinions of others;

- initiative and proactivity;

- leadership;

- empathy. 
The questionnaire aims to assess participation in different areas of university life and social life, and the level of actual social commitment. To do so, we present them with a series of situations and they choose the option which best represents them. The items refer to matters such as the areas in which they participate both at the university and elsewhere, their reasons for participation, their political participation, subjects which interest them, and, of course, the use they make of the media and social networks.

Looking at the subjects attracting the greatest interest, we find that the young women are more interested in environmental and solidarity issues, and the young men in sports and political issues. The results also reveal that $98 \%$ of students in the sample are habitual users of at least one social network; only $2 \%$ have created no profiles. Approximately $80 \%$ use them to contact friends and acquaintances. Although young men split their use, about $20 \%$ use them to participate in social or entertainment events. There is a very low percentage, approximately $9 \%$, who state that they use them to participate in opinion polls.

When analysing the use of social media in relation to the course studied, we find that Communication students make significantly more use of social media than the other students. More students from this faculty have created a social group, join more groups and social events and also participate more in opinion polls.

From the results shown, we should highlight that, despite the high percentage of students who use social media, only around $20 \%$ use it for entertainment or social events; and the percentage of participation in opinion polls is very low. The fact that Audiovisual Communication students, the best equipped in terms of using the media, have the highest results in participative aspects leads us to consider the benefit of fostering social participation by means of media education.

\section{FINAL THOUGHTS}

Media and digital education is a key issue in forming the future citizens of an ever-more interconnected world. However, for this to occur 
successfully and achieve the hoped-for results, we need sensitive families, well-trained teachers, responsible communication media professionals and dedicated political authorities.

Having considered how certain European education systems deal with media education in this work, we can state that support from the establishment and from civil society for the work performed by teachers is a deciding factor in good practice among teaching staff.

Second, following UNESCO guidelines, we have considered the aspects and skills within media and information education: access, evaluation and ethical use of information; comprehension of media functions; the possibility of creating information, and also understanding, critical thinking, intercultural awareness and citizenship are aspects forming the foundations of a practical educational proposal. In our opinion, these aspects should define the school curriculum for the subject. As Hobbs (2011) states, this means developing interdisciplinary research to examine in greater depth any pedagogical practices that uphold proper use of the media in education.

Finally, we have deliberated on the concept of media citizenship and on the digital spaces where young people have their citizenship experiences. The results show the need to foster social participation by means of media education. We consider that education in media competence and in social and civic competence have points in common, and therefore efforts to promote young people's media literacy will reflect better civic education and vice versa. This means that when working on specific aspects of media literacy in the classroom, we should emphasise certain points which contribute, for example, to civic participation from the students; and that when developing social and civic competences in schools, we cannot rule out using the media and exercising citizenship in the digital area. Martens $(2010,14)$ suggests an interesting turning point when he states "future research should more explicitly disentangle and describe the whole variety of cognitive abilities that media literacy encompasses».

Education plays a fundamental role at the core of the communication and information society, sharing technical, pedagogical and ethical-civic aspects of the use of the media (Gonzálvez, 2012). We, as 
citizens, need abilities that will keep us on a par with the demands of the new digital world, not merely by learning new technical skills, but by having a better understanding of the opportunities, challenges and even the ethical issues posed by the new technologies. In this way, people will acquire the knowledge, skills and competences which will allow them to understand and make appropriate use of these technologies. In the same way, it would seem expedient to continue looking into the efficacy of media literacy education, by attempting to single out the factors which may be of assistance, such as assessing the impact of the instruction methods: exploration of the role played by the individual differences; the influence of social contexts, among others. And finally, we must confirm that, as in all kinds of education, media education must be carried out in and by practice, «the person must actively and mindfully use the information in those knowledge structures during exposures to media messages» (Potter, 2004, 61). In this way we see the simultaneous simplicity and complexity demanded by promoting media and audiovisual competence.

\section{REFERENCES}

Aguaded, I. (2009). El Parlamento Europeo apuesta por la alfabetización mediática. Comunicar, 32, 7-8.

Bawden, D. (2008). Origins and concepts of digital literacy. In C. Lankshear \& M. Knobel (Eds.). Digital literacies: concepts, policies and practices. New York: Peter Lang.

Bazalgette, C. (1996). La enseñanza de los medios de comunicación en la enseñanza primaria y secundaria. In R. Aparici (coord.). La revolución de los medios audiovisuales. Educación y nuevas tecnologías (pp. 121-141). Madrid: Ediciones de la Torre.

Bazalgette, C. (2007a). Media education in the UK. Comunicar, 28, 33-41. 
Bazalgette, C. (2007b). La Carta Europea para la alfabetización en los medios de comunicación. Comunicar, 28, 140-142.

Bevort, E. (2007). Media education in France: a hard consolidation with good prospects. Comunicar, 28, 43-48.

Buckinham, D. (2007). Media education goes digital: an introduction. Learning, Media and Technology, 32 (2), 111-119.

Buckingham, D. \& Martínez-Rodríguez, J.B. (2013). Interactive youth: new citizenship between social networks and school settings. Comunicar, 40, 10-13.

Bundy, A. (Ed.) (2004). Australian and New Zealand information leteracy framework, principles, standards and practice. Adelaide: Australian and New Zealand Institute for Information Literacy.

Campuzano, A. (1992). Tecnologías audiovisuales y educación. Una visión desde la práctica. Madrid: Akal.

Comisión Europea (2007). Competencias clave para el aprendizaje permanente. Un marco de referencia europeo. Luxemburgo: Oficina de Publicaciones Oficiales de las Comunidades Europeas. URL (last cheked 13 August 2013) http:/ / ec.europa.eu/dgs/education culture / publ/pdf/ll-learning / keycomp es.pdf

Comisión Europea (2009). Council conclusions of 12 May 2009 on a strategic framework for European cooperation in education and training (ET 2020) Official Journal of the European Union, 2009/C 119/2 28.5.2009. URL (last cheked 13 August 2013) http: / / eur-lex. europa.eu/LexUriServ/ LexUriServ.do?uri=OJ:C:2009:119:0002: 0010:EN:PDF

De Pablos, J. (1996). Tecnología y educación. Barcelona: Cedecs.

Federici, S., Mamberto, R. \& Orlandini, B. (2003). Panorama della media education in alcuni paesi europei. XXI, Revista de Educación, 5, 71-80. 
Ferrer, A. M. \& Alcantud, F. (1995). La tecnología de la información en el medio escolar. Valencia: NAU llibres.

Fuentes, J.A. (2007). Los medios de comunicación en los documentos curriculares de EI, EP y ESO. In J. A. Ortega \& A. Chacón (coord.). Nuevas tecnologías para la educación en la era digital (pp. 43-54). Madrid: Ediciones Pirámide.

Gabelas, J.A. (2007). A view of media education in Spain. Comunicar, 28, 69-73.

Gallado, E.E. (2013). Competencia digital: revisión integradora de la literatura. Revista de Ciencias de la Educación Academicus, 1(3), 56-62.

García Jimenez, J. (1982). La radio television educative en Gran Bretaña. La BBC. In MEC, Educación y medios de comunicación. Informe final del Grupo Mixto de trabajo MEC-RTVE sobre Radio y Televisión Educativa (pp. 202-211). Madrid: MEC.

García-Valcarcel, A. (2003). Tecnología educativa. Implicaciones educativas del desarrollo tecnológico. Madrid: La Muralla.

García-Ruíz, R. y Renés, P. (2013). Educación mediática en la sociedad actual. Edmetic, Revista de Educación Mediática y TIC, 2:2, 3-7. URL (last cheked 13 August 2013) http:/ / www.edmetic.es/ Documentos/Vol2Num2-2013/p.pdf

Gilster, P. (1997). Digital literacy. New York: Wiley.

Gómez Vaquero, L. y García, N. (2002). Los medios audiovisuales en la educación secundaria dentro del marco de la Unión Europea: Francia, Reino Unido e Italia. Tarbiya: Revista de investigación e innovación educativa, 31, 83-106.

Gonzálvez, V. (2012). Ciudadania mediática. Una mirada educativa. Madrid: Dykinson. 
Guo-Ming, Ch. (2007). Media (literacy) education in the United States. China Media Research, 3(3), 87-103.

Gutiérrez, A \& Tyner, K. (2012). Educación para los medios, alfabetización mediática y competencia digital. Comunicar, 38, 31-39.

Hart, A. \& Hicks, A. (2002). Teaching media in the English curriculum. Stoke on Trent, UK: Trentham Books.

Hawkins, R. \& Paris, A.E. (1997). Computer literacy and computer use among college students: differences in black and White. Journal of Negro Education, 66(2).

Higgins, J.W. (1999). Community television and the vision of media literacy, social action, and empowerment. Journal of Broadcasting E Electronic Media, 43(4), 624-644.

Hobbs, R. (2011). The state of media literacy: a response to Potter. Journal of Broadcasting $\mathcal{E}$ Electronic Media, 55(3), 419-430.

Hoskins, B., Saisana, M. \& Villalba, C. M. H. (2015) Civic Competence of Youth in Europe: Measuring Cross National Variation through the Creation of a Composite Indicator. Social Indicator Research, 123, 2, 431-457. http:/ / link.springer.com/article/10.1007/ s11205-014-0746-z\#

Kubey, R. (2003). Why US media education lags behind the rest of the English-speaking world. Television New Media, 4(4), 351370 .

Livingstone, S. (2004). Media literacy and the challenge of new information and communication technologies. The Communication Review, 7(1), 3 - 14.

Martens, H. (2010). Evaluating Media Literacy Education. Concepts, Theories, and Future Directions. Journal of Media Literacy Education, 2(1), 1-22. 
Masterman, L. (1993). La enseñanza de los medios de comunicación. Madrid: Ediciones de la Torre.

Mena, B., Marcos, M. \& Mena, J.J. (1996). Didácticas y nuevas tecnologías en educación. Madrid: Escuela Española.

Morán, M. (1996). ¿Por qué educar para la comunicación? In R. Aparici (coord.). La revolución de los medios audiovisuales. Educación y nuevas tecnologías (pp. 55-58). Madrid: Ediciones de la Torre.

Ofcom (2012). Children and parents: media use and attitudes report. URL (last cheked 15 June 2013) http://stakeholders.ofcom.org. uk/market-data-research/media-literacy-pubs/

Parlamento Europeo. Informe sobre la alfabetización de los medios de comunicación en un mundo digital (2008/2129(INI). URL (last cheked 20 June 2013) http://www.europarl.europa. eu/sides/ getDoc.do?pubRef=-//EP//TEXT+ REPORT+A6-2008$\underline{0461+0+\mathrm{DOC}+\mathrm{XML}+\mathrm{V} 0 / / \mathrm{ES}}$

Pavón, F. (2005). Educación para las nuevas tecnologías. Pixel-Bit. Revista de Medios y Educación, 25, 5-17.

Pérez-Tornero, J.M. \& Martínez, J.F. (2011). Hacia un sistema supranacional de indicadores mediáticos. Infoamérica ICR, 5, 39-57.

Potter, W.J. (2004). Argument for the need for a cognitive theory of media literacy. American Behavioral Scientist, 48(2), 266-272.

Potter, W.J. (2010). The state of media literacy. Journal of Broadcasting E Electronic Media, 54(4), 675-696.

Ramasubramanian, S. (2007). Media-based strategies to reduce racial stereotypes activated by news stories. Journalism $\mathcal{E}$ Mass Communication Quarterly, 84(2), 249-264.

Ramasubramanian, S. \& Oliver M.B. (2007). Activating and suppressing hostile and benevolent racism: Evidence for comparative media stereotyping. Media Psychology, 9(3), 623-646. 
Recomendación 2006/962/CE del Parlamento Europeo y del Consejo, de 18 de diciembre de 2006, sobre las competencias clave para el aprendizaje permanente. URL (last checked 11 June 2013) http:/ / www.mcu.es/cine/ docs/Novedades/Recomendacion Parlamento Europeo Consejo Aprendizaje permanente.pdf

Reichert, T., LaTour, M.S., Lambiase, J.I. \& Adkins, M. (2007). A test of media literacy effects and sexual objectification in advertising. Journal of Current Issues \& Research in Advertising, 29(1), 81-92.

Reparaz, C., Arbués, E., Naval, C. y Ugarte, C. (2015). El índice cívico de los universitarios: sus conocimientos, actitudes y habilidades de participación social. Revista española de pedagogía, 260, 23-51.

Rivoltella, P.C. (2007). Italian media educational situation and challenges for the next future. Comunicar, 28, 17-24.

Rosenbaum, J. E., Beentjes, J. W. J. \& Konig, R. P. (2008). Mapping media literacy: Key concepts and future directions. In C. S. Beck (ed.). Communication Yearbook 32 (pp. 313-353). New York: Routledge.

Sancho, J. M. (2001). Repensando el significado y metas de la educación en la sociedad de la información. El efecto fractal. In M. Ara (coord). Educar en la sociedad de la información (pp. 37-79). Bilbao: Desclée.

Sloam, J. (2014), 'The outraged young': young Europeans, civic engagement and the new media in a time of crisis, Information, Communication $\mathcal{E}$ Society, Vol. 17, No. 2, pp. 217-231, http://dx. doi.org/10.1080/1369118 X.2013.868019

Steinke, J., Lapinski, M.K., Crocker, N., Zietsman-Thomas, A., Williams, Y., Evergreen, S.H. \& S. Kuchibhotla (2007). Assessing media Influences on middle school-aged children's perceptions of women in science using the Draw-A-Scientist Test (DAST). Science Communication, 29(1): 35-64. 
Thoman, E., \& T. Jolls (2004). Media literacy. A national priority for a changing world. American Behavioral Scientist, 48(1), 18-29.

Tulodziecki, G. \& Padeborn, S.G. (2007). Media education in Germany: development and current situation. Comunicar, 28, 61-68.

UNESCO (2008). Teacher Training Curricula for Media and information Literacy. Report of the International Expert Group Meeting. Paris: UNESCO. URL (last cheked 11 June 2013) http:/ / portal. unesco.org/ci/fr/files/27508/12212271723Teacher-Training Curriculum for MIL - final report.doc/Teacher Training $\% 2$ BCurriculum \%2Bfor $\%$ 2BMIL $\%$ 2B-\%2Bfinal $\% 2$ Breport.doc

Vargas, L., \& DePyssler, B. (1998). Using media literacy to explore stereotypes of Mexican immigrants. Social Education, 62(7), 407-412.

Wilson, C., Grizzle, A., Tuazon, R., Akyempong, K. \& Cheung, C. (2011). Media and Information literacy curriculum for teachers. Paris: UNESCO. 